\title{
Hyphomonas adhaerens sp. nov., Hyphomonas johnsonii sp. nov. and Hyphomonas rosenbergii sp. nov., marine budding and prosthecate bacteria
}

\author{
Ronald M. Weiner, ${ }^{1,2}$ Meredith Melick, ${ }^{1}$ Kathleen $\mathrm{O}^{\prime}$ Neill ${ }^{2}$ \\ and Ernesto Quintero 3
}

\begin{abstract}
Author for correspondence: Ronald M. Weiner. Tel: +1 301405 5446. Fax: + 13013149489. e-mail: rw19@umail.umd.edu
\end{abstract}

1,2 Department of Cell Biology and Molecular Genetics ${ }^{1}$, and Marine and Estuarine Sciences Program², University of Maryland, College Park, MD 20742, USA

3 Department of Biological Sciences, Universidad Santa Maria La Antigua, PO Box 6-1696 Eldorado Panama, Republic of Panama

\begin{abstract}
Three strains of prosthecate, budding bacteria, MHS- ${ }^{\top}$, MHS-3 ${ }^{\top}$ and $\mathrm{VP6}^{\top}$, were isolated from marine habitats including the open ocean (the pelagic zone), the offshore region (the neritic zone) and the hydrothermal vent region. A polyphasic approach including $16 \mathrm{~S}$ rDNA sequencing, phenotypic analyses, serology, fatty acid analyses, membrane protein profiles and DNA-DNA hybridizations was used to place these strains in the genus Hyphomonas, a taxon of the $\alpha$-Proteobacteria. The results of these analyses also showed that strains MHS-3 $3^{\top}$, MHS- ${ }^{\top}$ and VP6 $^{\top}$ each represent a new species of Hyphomonas. The names Hyphomonas adhaerens (type strain MHS-3', ATCC 43965'), Hyphomonas johnsonii (type strain MHS-2' ${ }^{\mathrm{T}}$, ATCC 43964') and Hyphomonas rosenbergii (type strain VP6 ${ }^{\top}$, ATCC $43869^{\top}$ ) are proposed for the new species. With these additions, Hyphomonas now contains eight species.
\end{abstract}

Keywords: Hyphomonas, prosthecate, budding bacteria, biofilm, marine bacteria

\section{INTRODUCTION}

Hyphomonas, along with Pedomicrobium, Hyphomicrobium, Rhodomicrobium (Urakami \& Komaga, 1987) and Hirschia (Schlesner et al., 1990), belongs to the budding/prosthecate bacteria (Fig. 1), a heterogeneous group in the $\alpha$-Proteobacteria (Stackebrandt et al., 1988) which includes more than 50 genera, including Agrobacterium, Rhodobacter, Nitrobacter and Rhizobium. This report adds three species to Hyphomonas and amends the description of the genus.

Pongratz (1957) first described the genus Hyphomonas upon isolating a budding, prosthecate bacterium from the nasal mucus of a diver with infectious sinusitis. It was subsequently named Hyphomonas polymorpha. It was given a new genus designation (Liefson, 1964)

Abbreviation: MPPI, membrane protein profile index.

The GenBank accession numbers for the Hyphomonas sequences reported in this paper are as follows: $H$. adhaerens MHS-3', AF082790; $H$. hirschiana $\mathrm{VP5}^{\top}$, AF082794; H. jannaschiana VP1, AF082799; $H$. jannaschiana VP2', AF082789; H. jannaschiana VP3, AF082792; H. jannaschiana VP4, AF082793; $H$. johnsonii MHS-2 ${ }^{\top}$, AF082791; $H$. neptunium LE670', AF082798; H. oceanitis SCH89', AF082797; H. polymorpha PR727', AF082796; H. rosenbergii VP6 ${ }^{\top}$, AF082795. because, although morphologically similar to Hyphomicrobium (Stutzer \& Hartleb, 1898) and Rhodomicrobium (Duchow \& Douglas, 1949), it was physiologically different. Since 1957, four additional species have been added to the genus. Hyphomonas neptunium was moved from Hyphomicrobium to Hyphomonas on the basis of DNA homology (Moore et al., 1984) and physiology (Havenner et al., 1979). Hyphomonas oceanitis, Hyphomonas jannaschiana and Hyphomonas hirschiana were added in 1985 (Weiner et al., 1985). All of the species thus far classified as Hyphomonas have been isolated from diverse marine or estuarine econiches.

On the basis of nearly identical biphasic, morphogenic life cycles, it was believed that Hyphomonas shared a very close relationship with Hyphomicrobium. Differentiation of Hyphomicrobium and Hyphomonas by means of morphology, DNA base composition (57-65 mol\% G+C; Gebers et al., 1984, 1985; Mandel et al., 1972) and genome size (Kolbel-Boelke et al., 1985; Moore \& Hirsch, 1973) did not dispel this notion. The only obvious phenotypic differences were that Hyphomicrobium species utilized one-carbon compounds for carbon and energy (Hirsch, 1974; Harder et al., 1975), whereas Hyphomonas species catabolized 


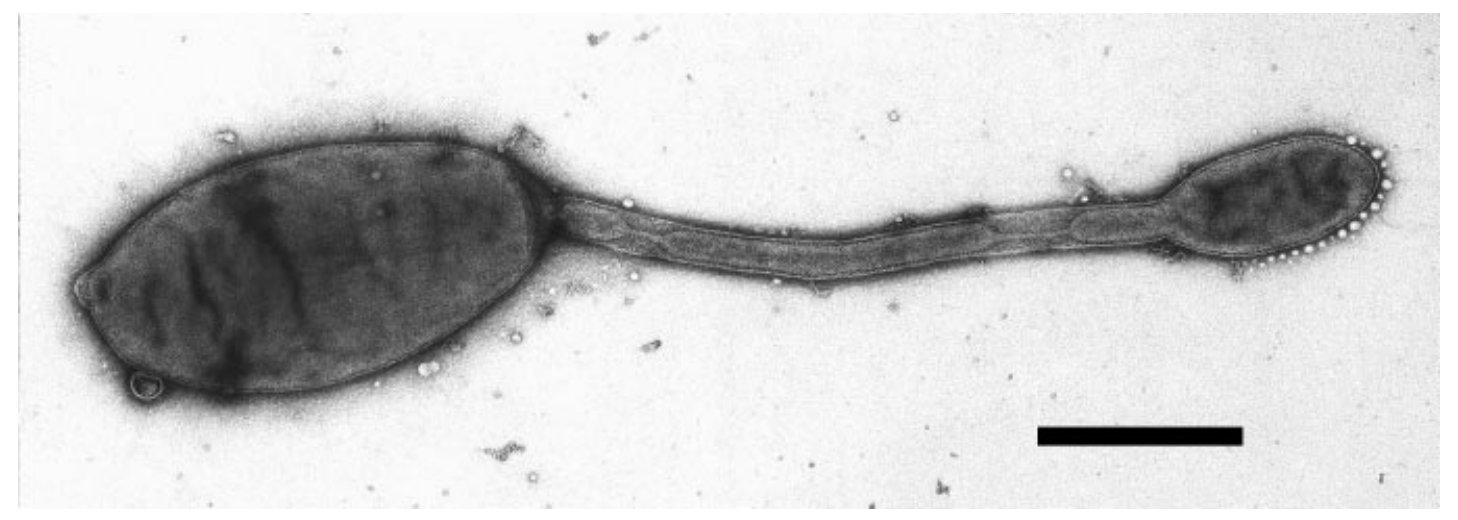

Fig. 1. Hyphomonas adhaerens sp. nov. strain MHS $-3^{\top}$ negatively stained with uranyl acetate and viewed by transmission electron microscopy. The main body of the reproductive cell, the prosthecum and the progeny (forming) bud are visible. Bar, $1 \mu \mathrm{m}$. Reprinted with the permission of the American Society for Microbiology.

proteins, peptides and amino acids and had an absolute requirement for $>1 \%$ marine salt formulations (Pongratz, 1957; Havenner et al., 1979; Moore et al., 1984).

Molecular taxonomic approaches have supported the phenotypically based placements (Moore \& Weiner, 1984) of many prosthecate bacteria into one of three genera, i.e. Hyphomicrobium, Hyphomonas or Caulobacter. The initial confirmation came when the $\mathrm{G}+\mathrm{C}$ content of the DNA (mol\%) was plotted against genome size and nucleotide distribution (KolbelBoelke et al., 1985; Gebers et al., 1985). rRNA-cistron similarities (Moore, 1977; Roggentin \& Hirsch, 1989), DNA-DNA hybridization data (Moore \& Hirsch, 1972; Gebers et al., 1986) and quinone, fatty acid, hydroxy fatty acid and phospholipid profiles (Sittig \& Hirsch, 1992; Sittig \& Schlesner, 1993) also justified (or did not contradict) the placements.

Recent taxonomic studies based on 16S rDNA analyses have revealed that the marine "evolutionary line of descent' (Stahl et al., 1992) of Caulobacter species demonstrates a closer relationship with Hyphomonas species than that between Hyphomicrobium species and Hyphomonas. Also, saltwater caulobacters are, remarkably, more closely related to Hyphomonas than they are to freshwater caulobacters (Stahl et al., 1992). Thus, marine physiology (i.e. the ability to pass macromolecules through a prosthecum to progeny buds) may be a more unifying criterion than cell biology

Prosthecate- and budding bacteria are widespread in natural ecosystems (Moore, 1981) and may represent up to one-third of the total microbial biomass of some ecosystems (Hirsch, 1974; Nikitin \& Nikitina, 1978). They are found in environments as diverse as Antarctic sea ice (Bowman et al., 1997), fresh water (Staley et al., 1980), ocean hydrothermal vents (Jannasch \& Wirson, 1981) and soils (Hirsch, 1974). Many prosthecate species are oligotrophic (Poindexter, 1981) and evo- lutionarily remote from eutrophic bacteria (Nikitin et al., 1990).

Some of the prosthecate bacteria, in particular, Hyphomonas and Caulobacter, have been implicated as primary colonizers on submerged surfaces in the marine environment (Baier et al., 1983). They are not readily isolated though they can be well represented (Weidner et al., 1996). They have been at the forefront of several recent and ongoing studies involving their role in biofilm formation mediated by production of localized-capsule, extracellular, polymeric substances (holdfasts; see Quintero \& Weiner, 1995; Frolund et al., 1996; Baty et al., 1996; Stahl et al., 1992). Some of these biofilms have been shown to mediate invertebrate set (macrofouling; see Chang et al., 1996). The mechanism of DNA segregation and the cell biology of capsule formation have also been elucidated recently (Langille \& Weiner, 1998; Quintero et al., 1998; Zerfas et al., 1997).

Hyphomonas species have a stereotypical biphasic life cycle (Wali et al., 1980), a G + C DNA content of 57-64 $\mathrm{mol} \%$, an optimum temperature range of $22-37^{\circ} \mathrm{C}$, a requirement for sea salts, a characteristic fatty acid fingerprint with octadecenoic acid (18:1) as the major fatty acid. Most species grow only with proteins, peptides and/or amino acids and synthesize $\mathrm{Q}_{11}$ as the major quinone (Urakami \& Komagata, 1987). Here we add the DNA-DNA overall similarity values and $16 \mathrm{~S}$ rDNA sequence matrices of all reported species of Hyphomonas to clarify the taxonomy of Hyphomonas; these and other criteria show that three additional isolates, MHS- $2^{\mathrm{T}}$, MHS- $3^{\mathrm{T}}$ and $\mathrm{VP} 6^{\mathrm{T}}$, each represent a new species.

\section{METHODS}

Strain and culture conditions. The strains used in this study are listed in Table 1. Hyphomonas neptunium, Hyphomonas jannaschiana, Hyphomonas hirschiana, Hyphomonas oceanitis and Hyphomonas polymorpha were maintained at 
Table 1. Source of Hyphomonas type strains used in this study

ATCC, American Type Culture Collection, Manassas, VA, USA. The temperatures shown are those used for cultivation.

\begin{tabular}{|c|c|c|c|c|}
\hline Hyphomonas species & Strain designation & ATCC no. & Temp. $\left({ }^{\circ} \mathrm{C}\right)$ & Isolation source \\
\hline H. polymorpha & $\mathrm{PS} 728^{\mathrm{T}}$ & 33881 & 30 & Nasal mucosa of diver \\
\hline H. jannaschiana & $\mathrm{VP} 2^{\mathrm{T}}$ & 33882 & 30 & Galapagos vent area \\
\hline H. hirschiana & $\mathrm{VP5}^{\mathrm{T}}$ & 33886 & 25 & Galapagos vent area \\
\hline H. oceanitis & $\mathrm{SCH} 89^{\mathrm{T}}$ & 33879 & 25 & Baltic Sea \\
\hline H. neptunium & LE670 ${ }^{\mathrm{T}}$ & 15444 & 30 & Barcelona Harbour \\
\hline H. johnsonii sp. nov. & MHS-2 $2^{\mathrm{T}}$ & 43964 & 30 & Mud slough \\
\hline H. adhaerens sp. nov. & MHS- $3^{\mathrm{T}}$ & 43965 & 30 & Mud slough \\
\hline H. rosenbergii sp. nov. & $\mathrm{VP}^{\mathrm{T}}$ & 43869 & 30 & Guayamas vent region \\
\hline
\end{tabular}

$-70{ }^{\circ} \mathrm{C}$ in our laboratory. Two of the three strains, belonging to the newly proposed species, were originally isolated and donated by J. Smit. Strain VP6 ${ }^{\mathrm{T}}$ was obtained from H. Jannasch. These strains were deposited in the American Type Culture Collection and also maintained in our laboratory at $-70{ }^{\circ} \mathrm{C}$.

Bacto Marine Broth 2216 (MB; Difco) was used for the routine culture of all strains. Solid marine media (MA) contained $2 \%$ Bacto agar (Difco). Working stock cultures were maintained on slants at $4{ }^{\circ} \mathrm{C}$. For characterizations, all strains were grown with aeration at 25,30 or $37^{\circ} \mathrm{C}$ and harvested during the exponential phase of growth. Growth was measured turbidimetrically. It was verified microscopically that the culture consisted of pure prosthecate/budding and swarm cells. Species purity was confirmed serologically.

Biochemical tests. The $\mathrm{pH}$ and temperature requirements were examined using MB. Salt requirements were determined using variable amounts of Instant Ocean (IO; Aquarium Systems), Bacto-peptone at $0.5 \%$ and yeast extract at $0 \cdot 1 \%$ (Difco). The $\mathrm{NaCl}$ concentration requirements were determined by using $30 \% \mathrm{MB}$ and adding increments of $\mathrm{NaCl}$. The biochemical tests were done as described by Smibert \& Krieg (1981), except that IO was used instead of sodium chloride at a final concentration of $2.5 \%$. Phenotypic tests included those for oxidase, urease, catalase, DNase, coagulase, gelatin hydrolysis, starch hydrolysis, citrate utilization, indole production, hydrogen sulfide production, gas from glucose, acid from mannose, sucrose, fructose, glucose, galactose and triple iron sugar, haemolysis on sheep-blood agar and nitrate reduction. The reagents were obtained from Sigma.

Inhibitors. The methods used for susceptibility testing were as described previously (Weiner et al., 1985). Tester strains Escherichia coli ATCC 25922 and Pseudomonas aeruginosa ATCC 27853 were used as standard controls. Streptomycin and penicillin Sensi-discs were obtained from BBL. Novobiocin, ampicillin and other inhibitory substances were purchased from Sigma and used to impregnate sterile blank discs at known concentrations. Inhibition by $1.0 \%$ Tween 80 was determined by incorporating it into the MA.

Fatty acid methyl ester analysis. All strains (Table 1) were grown at $27^{\circ} \mathrm{C}$ and harvested during the late-exponential phase of growth. Fatty acids were processed and analysed according to the methods of Lechevalier \& Lechevalier (1988).
Electrophoretic pattern of cell envelope protein. Cell envelope purification, membrane protein purification, SDSPAGE and membrane protein profile index (MPPI) calculations were done as described previously (Dagasan \& Weiner, 1986).

Serology. Rabbit antisera were produced against all strains, using formalin-killed cells harvested during the lateexponential phase of growth in $\mathrm{MB}$ as the antigens. The antisera were processed as described previously (Langille \& Weiner, 1998). The antigenic similarities of all Hyphomonas strains were tested against each antiserum using the ELISA with low-binding, easy-wash assay plates (Corning Glass Works). The secondary antibody was peroxidase-conjugated goat anti-rabbit (Sigma). Serological similarities (\%) among strains of Hyphomonas were calculated as (log of heterologous titre/log of homologous titre) $\times 100$. The ELISA readings were taken at an optical density of 1.5 (at an absorbance wavelength of $490 \mathrm{~nm}$ ) using a Lambda Reader (Perkin-Elmer). Alteromonas macleodii strain RF34650 ${ }^{\mathrm{T}}$ (= ATCC $27126^{\mathrm{T}}$ ) and antisera from rabbit prebleeds were used as negative controls.

Monoclonal antibodies to strain Hyphomonas MHS- $3^{\mathrm{T}}$ lipopolysaccharide were prepared as described previously (Quintero et al., 1998) and analysed by Western blotting of SDS-PAGE-separated lipopolysaccharide as described previously (Sledjeski \& Weiner, 1991)

DNA isolation, preparation and hybridization. DNA was isolated by using a variation of the Marmur (1961) procedure involving an extra phenol purification step. The purity of the DNA was determined spectrophotometrically and was considered acceptable with ratios of $1 \cdot 75-1 \cdot 85,260 / 280 \mathrm{~nm}$. The $\mathrm{G}+\mathrm{C}$ content ( $\mathrm{mol} \%$ ) was calculated from the thermal melting point $\left(T_{\mathrm{m}}\right)$ according to the methods of Johnson (1994). For the DNA-DNA hybridization studies, DNA was prepared, iodinated and analysed for overall similarity using the $\mathrm{S}_{1}$ Homology DNA free-solution hybridization technique described by Johnson (1994) and incorporating ${ }^{125} \mathrm{I}$ according to the procedures of Werman et al. (1996).

PCR amplification and cloning. rRNA genes (rDNA) were amplified by the PCR, using the universal 16S rRNA (rRNA) primer 1392R (5'-ACGGGCGGTGTGTRC-3') and the bacterial primer 27F (5'-AGAGTTTGATCMTGGCTCAG-3') (the numbers of the primers correspond to $E$. coli positions; $\mathrm{R}=$ purine, $\mathrm{M}=\mathrm{A}, \mathrm{C})$. The $\mathrm{PCR}$ was performed using $40 \mathrm{pmol}$ of each primer, $10 \mathrm{mM}$ Tris $/ \mathrm{HCl}$ 
(pH 8.8), $50 \mathrm{mM} \mathrm{KCl}, 0 \cdot 1 \%$ (w/v) gelatin, $2.5 \mathrm{mM} \mathrm{MgCl}_{2}$ and $10 \mathrm{mM}$ dNTP. Target rDNA was amplified (ABI 9600 thermocycler; Perkin-Elmer) by using the following PCR protocol: denaturing at $92^{\circ} \mathrm{C}$ for $30 \mathrm{~s}$, annealing at $55^{\circ} \mathrm{C}$ for $30 \mathrm{~s}$, and extension at $72^{\circ} \mathrm{C}$ for $1 \mathrm{~min}$ for 30 cycles with a final extension at $72^{\circ} \mathrm{C}$ for $15 \mathrm{~min}$. Amplification of the target rDNA was confirmed by agarose gel electrophoresis and a 377 automated sequencer (Perkin-Elmer) was used to obtain rDNA sequences from the PCR products.

Phylogenetic analysis. Sequences were analysed for chimera formation, after which phylogenetic analysis was performed using maximum-likelihood (Larsen et al., 1993) and a similarity matrix (Felsenstein, 1993). Sequences used for comparisons were obtained from the RNA Database Project (Larsen et al., 1993).

\section{RESULTS AND DISCUSSION}

\section{Phenotypic characteristics}

The phenotypic characteristics of Hyphomonas strains MHS- $2^{\mathrm{T}}$, MHS- $3^{\mathrm{T}}$ and $\mathrm{VP} 6^{\mathrm{T}}$ are summarized in Table 2. Each shared genus specific characteristics, e.g. prosthecate-budding morphology and a requirement for sea salts, yet were clearly different from one another. The fine structure, the colonial morphology and the mechanism of rosette formation (or lack thereof) of Hyphomonas MHS-3 ${ }^{\mathrm{T}}$ and $\mathrm{VP} 6^{\mathrm{T}}$ have been reported (Langille \& Weiner, 1998; Quintero \& Weiner, 1995).

VP6 ${ }^{\mathrm{T}}$ had a broader optimum growth temperature $\left(25-45^{\circ} \mathrm{C}\right)$ than the other two new strains $\left(25-37^{\circ} \mathrm{C}\right)$. It also produced a reddish brown pigment (a pyomelanin; Kotob et al., 1995). Of all the strains of Hyphomonas, only MHS- $2^{\mathrm{T}}$ used sugars as the sole carbon source for growth. Each of the three new isolates was oxidase-positive, catalase-positive and urease-negative. None hydrolysed starch or gelatin or utilized citrate. None produced indole or hydrogen sulfide.

None of the more recently acquired strains phenotypically matched closely enough with any of the extant Hyphomonas spp. to be considered an additional strain in an existing species. However, it would have been extremely difficult to identify properly the new strains to species using only phenotypic methods. The phenotypes, particularly the biphasic life cycle, the requirement for marine salts and the preferential utilization of peptone, were valuable in placing these strains in Hyphomonas.

Table 2. Phenotypic characteristics and $G+C$ content of the DNA of newly proposed species of Hyphomonas

The following characteristics applied to all three species: growth in broth was granular/ropy; cells grew in peptone as the sole carbon source; and cells were susceptible to streptomycin $(10 \mu \mathrm{g})$ and SDS $(0.2 \mathrm{mg})$ but resistant to neutral red $(80 \mu \mathrm{g})$ and Tween $80(1.0 \%)$. Abbreviations: VS; very susceptible (diameter of inhibition zone, $>20 \mathrm{~mm}$ ); S, susceptible (diameter of inhibition zone, 10-20 mm); R, resistant (diameter of inhibition zone, $<10 \mathrm{~mm}$ ).

\begin{tabular}{|lccc|}
\hline Characteristic & $\begin{array}{c}\text { H. adhaerens } \\
\text { MHS-3 }^{\mathbf{T}}\end{array}$ & $\begin{array}{c}\text { H. johnsonii } \\
\text { MHS-2 }^{\mathbf{T}}\end{array}$ & $\begin{array}{c}\text { H. rosenbergii } \\
\text { VP6 }^{\mathbf{T}}\end{array}$ \\
\hline Optimal temp. for growth $\left({ }^{\circ} \mathrm{C}\right)$ & $25-37$ & $25-37$ & $25-45$ \\
Ocean salts growth range & $1 \cdot 5-12 \cdot 0$ & $1 \cdot 5-6 \cdot 0$ & $1 \cdot 0-12 \cdot 0$ \\
Film formation on growth vessel & +++ & $-/+$ & ++ \\
Optimal pH range & $5 \cdot 7-8 \cdot 7$ & $5 \cdot 7-8 \cdot 1$ & $5 \cdot 7-8 \cdot 9$ \\
Haemolysis on sheep-blood agar & Gamma & Alpha & Gamma \\
Rosette formation & - & + & + \\
Pyomelanin production & $+/-$ & $+/-$ & + \\
Susceptibility to: & & & \\
Novobiocin $(30 \mu \mathrm{g})$ & $\mathrm{S}$ & $\mathrm{S}$ & $\mathrm{VS}$ \\
Penicillin $(10 \mathrm{U})$ & $\mathrm{R}$ & $\mathrm{S}$ & $\mathrm{S}$ \\
Ampicillin $(10 \mu \mathrm{g})$ & $\mathrm{R}$ & $\mathrm{S}$ & $\mathrm{VS}$ \\
Tellurite $(0 \cdot 1 \mathrm{mg})$ & $\mathrm{VS}$ & $\mathrm{VS}$ & $\mathrm{S}$ \\
Crystal violet $(40 \mu \mathrm{g})$ & $\mathrm{S}$ & $\mathrm{VS}$ & $\mathrm{S}$ \\
Brilliant green $(40 \mu \mathrm{g})$ & $\mathrm{S}$ & $\mathrm{VS}$ & $\mathrm{S}$ \\
Methylene blue $(2 \cdot 0 \mathrm{mg})$ & $\mathrm{VS}$ & $\mathrm{R}$ & $\mathrm{S}$ \\
Neutral red $(160 \mu \mathrm{g})$ & $\mathrm{S}$ & $\mathrm{R}$ & $\mathrm{R}$ \\
Methyl violet $(16 \mu \mathrm{g})$ & $\mathrm{R}$ & $\mathrm{S}$ & $\mathrm{S}$ \\
Growth in glucose* & - & + & - \\
DNA G+C content $(\mathrm{mol} \%) \dagger$ & 60 & 64 & 61 \\
\hline
\end{tabular}

* Sole carbon source.

$\dagger$ This study and personal communication (R. Gherna). 
Table 3. Fatty acid profiles of Hyphomonas

Total fatty acid values are rounded up to the nearest one per cent of total detected fatty acids. Abbreviations: SH, Sittig \& Hirsch (1992) (cells harvested in the late-exponential phase at $25^{\circ} \mathrm{C}$ ); TS, this study (cells harvested in the late-exponential phase at $27^{\circ} \mathrm{C}$ ); UK, Urakami \& Komagata (1987) (cells harvested during stationary phase at $30^{\circ} \mathrm{C}$ ); ND, no data.

\begin{tabular}{|c|c|c|c|c|c|c|c|c|}
\hline \multirow[t]{2}{*}{ Species/strain } & \multirow[t]{2}{*}{ Reference } & \multicolumn{6}{|c|}{ Total fatty acids (\%) } & \multirow[b]{2}{*}{ n18:1 } \\
\hline & & n15:0 & n16:0 & n16: 1 & n17:0 & cyc17:0 & n17:1 & \\
\hline \multirow[t]{3}{*}{ H. neptunium $\mathrm{LE} 670^{\mathrm{T}}$} & $\mathrm{SH}$ & 10 & 5 & 1 & 19 & ND & 18 & 19 \\
\hline & $\mathrm{TS}$ & 8 & 8 & 4 & 10 & ND & 14 & 37 \\
\hline & UK & 8 & 2 & 2 & 16 & 55 & ND & 10 \\
\hline \multirow[t]{3}{*}{ H. polymorpha $\mathrm{PS} 728^{\mathrm{T}}$} & $\mathrm{SH}$ & 9 & 0 & 1 & 25 & ND & 14 & 12 \\
\hline & $\mathrm{TS}$ & 6 & 2 & 1 & 23 & ND & 24 & 15 \\
\hline & UK & 10 & 2 & 2 & 19 & 44 & ND & 10 \\
\hline \multirow[t]{3}{*}{ H. oceanitis $\mathrm{SCH} 89^{\mathrm{T}}$} & $\mathrm{SH}$ & 0 & 34 & 6 & 0 & ND & 0 & 53 \\
\hline & TS & 0 & 27 & 6 & 0 & ND & 0 & 49 \\
\hline & UK & 0 & 22 & 13 & 1 & 1 & ND & 60 \\
\hline \multirow[t]{3}{*}{ H. jannaschiana $\mathrm{VP} 2^{\mathrm{T}}$} & $\mathrm{SH}$ & 5 & 4 & 1 & 18 & ND & 14 & 22 \\
\hline & TS & 5 & 2 & 0 & 31 & ND & 22 & 11 \\
\hline & UK & 1 & $7 \cdot 2$ & 3 & 6 & 10 & ND & 65 \\
\hline \multirow[t]{3}{*}{ H. hirschiana $\mathrm{VP}^{\mathrm{T}}$} & $\mathrm{SH}$ & 0 & 30 & 2 & 0 & ND & 0 & 54 \\
\hline & TS & 7 & 9 & 3 & 11 & ND & 13 & 39 \\
\hline & UK & 1 & 9 & 7 & 2 & 11 & ND & 67 \\
\hline H. johnsonii sp. nov. MHS-2 $2^{\mathrm{T}}$ & TS & 0 & 21 & 3 & 0 & ND & 0 & 64 \\
\hline H. adhaerens sp. nov. MHS- $3^{T}$ & TS & 0 & 10 & 2 & 0 & ND & 0 & 80 \\
\hline H. rosenbergii sp. nov. $\mathrm{VP}^{\mathrm{T}}$ & TS & 2 & 32 & 6 & 0 & ND & 3 & 43 \\
\hline
\end{tabular}

\section{$\mathbf{G}+\mathbf{C}$ content}

Table 2 shows the $\mathrm{G}+\mathrm{C}$ content of $\mathrm{MHS}-2^{\mathrm{T}}, \mathrm{MHS}-3^{\mathrm{T}}$ and $\mathrm{VP}^{\mathrm{T}}$ to be between 60 and $64 \mathrm{~mol} \%$, strains MHS $-3^{\mathrm{T}}$ and $\mathrm{VP} 6^{\mathrm{T}}$ falling within the existing range of Hyphomonas species. The $\mathrm{G}+\mathrm{C}$ content of strain MHS- ${ }^{\mathrm{T}}$ was $2 \mathrm{~mol} \%$ higher than that of any other strain of Hyphomonas.

\section{Fatty acid profiles}

There are three separate studies on the fatty acid profiles of all but the newly proposed species of Hyphomonas and the results are included for purposes of comparison (Table 3). There was a consensus on most, but not all, profiles among the three studies. Variance was attributed to different conditions of cultivation, especially temperature and the phase of growth at harvesting. This study and that of Sittig \& Hirsch (1992) harvested cells under similar conditions and the results are generally in good agreement.

Sittig \& Hirsch (1992) and Urakami \& Komagata (1987) examined several genera of budding/ prosthecate bacteria, including Hyphomonas. Hyphomicrobium spp. were found to contain, on average, approximately $75 \%$ octadecenoic acid, while all the other fatty acids constituted only $0 \cdot 2-13 \cdot 2 \%$ of the total. Hyphomonas was the only genus, among the budding/prosthecate bacteria studied, in which some species, e.g. Hyphomonas neptunium and Hyphomonas polymorpha, contained higher amounts of hepta- decanoic (17:0) and heptadecenoic acids (17:1) than octadecenoic acid (18:1; Sittig \& Hirsch, 1992). In fact, species of Hyphomonas contained a mean of $50 \%$ octadecenoic acid as opposed to approximately $75 \%$ for species of Hyphomicrobium.

Like the analyses of phenotype and $\mathrm{G}+\mathrm{C}$ content, the fatty acid profiles did not preclude placement of the new isolates into Hyphomonas. Indeed, they supported such placement. All Hyphomonas species synthesized high percentages of octadecenoic acid (18:1; Table 3), albeit in varying amounts. These ranged from $11 \%$ in Hyphomonas jannaschiana to $80 \%$ in MHS- $3^{\mathrm{T}}$, a value exceeding those of all extant Hyphomonas species but correlating well with those of most other budding/ prosthecate bacteria (i.e. Rhodomicrobium, Pedomicrobium and Hyphomicrobium; Urakami \& Komagata, 1987; Sittig \& Hirsch, 1992). Hyphomonas was also found to contain novel lipids (Batrakov et al., 1996).

\section{Membrane protein}

Under defined growth parameters, the membrane protein content of bacteria is characteristic for each species (Dagasan \& Weiner, 1986) and therefore serves as a useful taxonomic tool (Vauterin et al., 1993). Hyphomonas species synthesized at least four outermembrane proteins with high apparent molecular masses $(>100 \mathrm{kDa})$, which is a distinguishing characteristic of this genus (Shen et al., 1989; Dagasan \& 


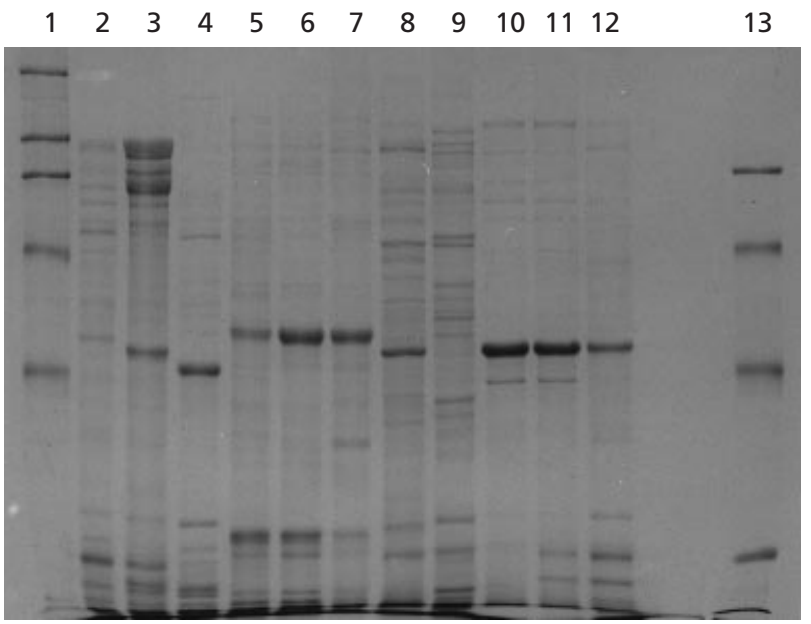

Fig. 2. SDS-PAGE of membrane proteins of seven strains of Hyphomonas. The gels were stained with Coomassie brilliant blue R-250. Lanes: 1, high-molecular-mass standards (170, 116, 92, 66 and $45 \mathrm{kDa}) ; 2$, strain VP1 $(H$. jannaschiana); 3, strain $\mathrm{VP}^{\top}$ ( $H$. jannaschiana); 4, strain $\mathrm{VP}^{\top}{ }^{\top}$ ( $H$. hirschiana); $5-7$, strain $\mathrm{VP6}^{\top}$ (proposed as $H$. rosenbergii); 8 , unclassified strain MHS-1; 9, strain $\mathrm{MHS}-2^{\top}$ (proposed as $H$. johnsonii); 10-12, strain MHS- $3^{\top}$ (proposed as $H$. adhaerens); 13, low-molecular-mass standards $(9266,45,31$ and $14.4 \mathrm{kDa})$.

Table 4. Serological similarities (\%) among strains of Hyphomonas

Strains: MHS-2 $2^{\mathrm{T}}, H$. johnsonii sp. nov.; MHS- $3^{\mathrm{T}}, H$. adhaerens sp. nov.; VP1-VP4, $H$. jannaschiana; $\mathrm{VP}^{\mathrm{T}}, H$. hirschiana; $\mathrm{VP}^{\mathrm{T}}, H$. rosenbergii sp. nov.; $\mathrm{LE} 60^{\mathrm{T}}, H$. neptunium; $\mathrm{SCH} 89^{\mathrm{T}}, H$. oceanitis; $\mathrm{PS} 728^{\mathrm{T}}$ and $\mathrm{PR} 727, H$. polymorpha.

\begin{tabular}{|lrrrr|}
\hline \multirow{2}{*}{ Antiserum to strain } & \multicolumn{4}{c|}{ Whole-cell strain: } \\
\cline { 2 - 5 } & MHS-2 $^{\text {T }}$ & MHS-3 $^{\mathbf{T}}$ & VP1 & VP6 $^{\mathbf{T}}$ \\
\hline MHS-2 $^{\mathrm{T}}$ & 100 & 47 & 52 & 50 \\
MHS-3 $^{\mathrm{T}}$ & 48 & 100 & 45 & $<38$ \\
VP1 & 72 & 72 & 100 & 66 \\
VP2 $^{\mathrm{T}}$ & 62 & 68 & 76 & 68 \\
VP3 & 71 & 74 & 97 & 68 \\
VP4 & 48 & 70 & 88 & 51 \\
VP5 $^{\mathrm{T}}$ & 61 & 61 & 47 & 59 \\
VP6 $^{\mathrm{T}}$ & 54 & 56 & 63 & 100 \\
LE670 $^{\mathrm{T}}$ & 62 & 49 & 39 & 38 \\
SCH89 $^{\mathrm{T}}$ & 69 & 58 & 50 & 38 \\
PS728 $^{\mathrm{T}}$ & 38 & 39 & 42 & 38 \\
PR727 $^{\text {Alteromonas macleodii }}$ & 38 & 39 & 39 & 44 \\
\hline
\end{tabular}

Weiner, 1986). The results for the MPPI supported the division of extant members of this genus into five species (Dagasan \& Weiner, 1986).

The MPPIs of strains MHS-2 ${ }^{\mathrm{T}}$, MHS- $3^{\mathrm{T}}$ and VP6 ${ }^{\mathrm{T}}$ were also revealing (Fig. 2). They ranged from 30 to
$80 \%$ MPPI similarity with the other species of Hyphomonas, suggesting their placement in Hyphomonas as unique species. MHS- $3^{\mathrm{T}}$ (lanes 10-12) and VP6 ${ }^{\mathrm{T}}$ (lanes 5-7) synthesized substantial amounts of a Hyphomonas signature protein (approx. 46-48 kDa; Dagasan \& Weiner, 1986). MHS-2 ${ }^{\mathrm{T}}$ (lane 9) had the most unique protein profile and, unlike all the other strains, did not synthesize a very high-copy-number protein. It did, however, synthesize genus-typical (Dagasan \& Weiner, 1986) 31 and $36 \mathrm{kDa}$ proteins.

\section{Serology}

Table 4 shows the serological relatedness of the more recently isolated strains of Hyphomonas to one another and to the extant strains. The homologous reaction was set to $100 \%$ similarity and negative controls had less than $45 \%$ similarity. Different strains of the same species normally had $>75 \%$ similarity. Like the MPPI and phenotypes, the results must be considered in the larger framework of the molecular analyses. Only exposed antigens of whole cells would react with the strain-specific polyclonal antiserum and even these can be masked by the synthesis of surface structures such as capsules.

MHS- $2^{\mathrm{T}}$, MHS- $3^{\mathrm{T}}$ and VP6 ${ }^{\mathrm{T}}$ were related to the other species, averaging $55 \pm 10 \%, 58 \pm 12 \%$ and $52 \pm 12 \%$ similarity, respectively. Hyphomonas polymorpha and Hyphomonas oceanitis had the least serological identity with the new isolates, while Hyphomonas jannaschiana had the most. Hyphomonas jannaschiana and Hyphomonas rosenbergii, having higher growth temperature capabilities, generally had more serological similarity to one another than to other strains. As with the MPPI, this measure of serological relatedness was useful in identifying isolates as members of the genus Hyphomonas (Bowden, 1993) and, in some cases, in matching the most closely related strains (same species); however, it was not useful in determining the relatedness of different species of Hyphomonas to one another.

Monoclonal antibodies against the lipopolysaccharide of Hyphomonas strain MHS- $3^{\mathrm{T}}$ did not cross-react with that of any of the other 12 strains of Hyphomonas. This is consistent with the considerable antigenic variability that is characteristic of LPS (DeWeger et al., 1987).

\section{DNA-DNA hybridization}

Table 5 shows the results of hybridization between each extant Hyphomonas species and each of the newly proposed species. These results were in $>90 \%$ agreement with those of previous studies (only Hyphomonas polymorpha and Hyphomonas neptunium were previously tested; Moore \& Hirsch, 1972; Gebers et al., 1984). Of the new isolates, MHS- $3^{\text {T }}$ had the highest overall DNA-DNA similarity $(66 \%$ with another species, namely Hyphomonas neptunium). A guideline for the inclusion of different strains within the same 
Table 5. DNA homologies of the eight Hyphomonas species

Results were calculated as the relationship shown by at least three separate experiments, averaging six values including the reciprocal. All the values listed are combined means from the reciprocal hybridizations, which are within $10 \%$ of one another.

\begin{tabular}{|c|c|c|c|c|c|c|c|c|}
\hline Strain & MHS-3 $^{\mathrm{T}}$ & LE670 $^{\mathrm{T}}$ & MHS-2 $^{\mathrm{T}}$ & $\mathrm{VP5}^{\mathrm{T}}$ & $\mathrm{SCH} \mathrm{9}^{\mathrm{T}}$ & VP1 & PS728 $^{\mathrm{T}}$ & $\mathrm{VPG}^{\mathrm{T}}$ \\
\hline H. adhaerens sp. nov. MHS- $3^{\mathrm{T}}$ & 100 & & & & & & & \\
\hline H. neptunium LE670 & 66 & 100 & & & & & & \\
\hline H. johnsonii sp. nov. MHS-2 $2^{\mathrm{T}}$ & 25 & 25 & 100 & & & & & \\
\hline H. hirschiana $\mathrm{VP}^{\mathrm{T}}$ & 19 & 54 & 12 & 100 & & & & \\
\hline H. oceanitis SCH89 $9^{\mathrm{T}}$ & 11 & 12 & 23 & 20 & 100 & & & \\
\hline H. jannaschiana VP1 & 41 & 32 & 18 & 23 & 26 & 100 & & \\
\hline H. polymorpha $\mathrm{PS}_{2} 28^{\mathrm{T}}$ & 32 & 27 & 13 & 34 & 28 & 8 & 100 & \\
\hline H. rosenbergii sp. nov. $\mathrm{VP}^{\mathrm{T}}$ & 30 & 11 & 21 & 19 & 2 & 4 & 5 & 100 \\
\hline
\end{tabular}

species has been proposed to be $\geqslant 70 \%$ homology (Johnson, 1984). In comparison, Hyphomonas hirschiana averaged $26 \%$ homology and Hyphomonas jannaschiana averaged $22 \%$ homology with the other species of Hyphomonas.

MHS- $2^{\mathrm{T}}$ was the most distantly related new strain, yet falling, in most cases, within $20 \%$ overall DNA-DNA homology. The hybridization data were consistent with other criteria, such as the membrane protein profile and phenotypic characteristics, in placing MHS- $2^{\mathrm{T}}$ as a new, more outlying, species of Hyphomonas.

\section{Phylogenetic relationships}

The 16S rDNA nucleotide sequences of strains MHS$2^{\mathrm{T}}$ (1301 nucleotides), MHS-3 ${ }^{\mathrm{T}}$ (1334 nucleotides), VP6 ${ }^{\mathrm{T}}$ (1354 nucleotides), as well as the extant species PS728 (1309 nucleotides), VP1 (1352 nucleotides), VP2 (1368 nucleotides), VP3 (1351 nucleotides), VP4 (1354 nucleotides), VP5 (1354 nucleotides), SCH89 (1309 nucleotides) and LE670 (1316 nucleotides), were determined and deposited in the GenBank database.

Fig. 3 shows the similarity levels for the three newly proposed species and the five extant species. For Hyphomonas jannaschiana all four strains were included. Hyphomonas jannaschiana VP1 and MHS- $3^{\mathrm{T}}$ had been previously sequenced (Stahl et al., 1992), in each case having $>99.4 \%$ similarity with the same strain in this study.

The five existing and three proposed species had signature sequences that placed them in the $\alpha$-Proteobacteria (Stackebrandt et al., 1988). Each was related to the other above the $96 \%$ similarity level. A member of the most closely related genus, Hirschia (Schlesner et al., 1990), was related to each of the strains of Hyphomonas at the $90 \pm 1 \%$ similarity level. The $16 \mathrm{~S}$ rDNA sequence data supported previous findings that Hyphomonas, a genus of marine bacteria, is more closely related to the marine line of Caulobacter than to terrestrial, budding, prosthecate genera (e.g. Hyphomicrobium; Fig. 3).
Clearly, each of the new isolates (strains MHS-2 ${ }^{\mathrm{T}}$, MHS- $3^{\mathrm{T}}$ and $\mathrm{VP} 6^{\mathrm{T}}$ ) belong in the genus Hyphomonas. In addition to $16 \mathrm{~S}$ rDNA sequences and phenotypic characteristics, the DNA reassociation values, the MPPI, the serological identities and the fatty acid analysis all support the placements of these isolates. The DNA-DNA reassociation values provided the best (but not the only) criteria by which the strains were shown to represent three distinct and new species. None of these strains had reassociation values $>66 \%$ with any extant species, while all showed some DNADNA similarity. Thus, it is proposed that Hyphomonas should be revised by the addition of three new species, bringing the total to eight species comprising 13 strains.

\section{Interrelationship of Hyphomonas species based on genetic similarity}

The phylogenetic tree (Fig. 3) shows the relationships between each of the species of Hyphomonas according to $16 \mathrm{~S}$ rDNA sequence analysis. Hyphomonas rosenbergii sp. nov., Hyphomonas hirschiana, Hyphomonas polymorpha and Hyphomonas neptunium clustered at the $99.4 \%$ similarity level. Hyphomonas adhaerens sp. nov. and Hyphomonas jannaschiana (99.3\%) and, as expected, each of the strains of Hyphomonas jannaschiana were related at a high level $(99 \cdot 3 \%)$ as well. Hyphomonas johnsonii sp. nov. was most closely related to Hyphomonas oceanitis (a 98.7\% similarity level) but otherwise neither of these species was closely related to other species of Hyphomonas. The bootstrapping analyses support these placements (Fig. 3).

Thus, the 16S rDNA sequence analyses divide the eight species of Hyphomonas into: (i) a tight group of four species, i.e. Hyphomonas rosenbergii sp. nov., Hyphomonas hirschiana, Hyphomonas polymorpha and Hyphomonas neptunium; (ii) a group with two species, i.e. Hyphomonas adhaerens sp. nov. and Hyphomonas jannaschiana; and (iii) a less tight group of two species, i.e. Hyphomonas johnsonii sp. nov. and Hyphomonas oceanitis. Likewise, the DNA-DNA hybridization data show Hyphomonas neptunium to be closely related 


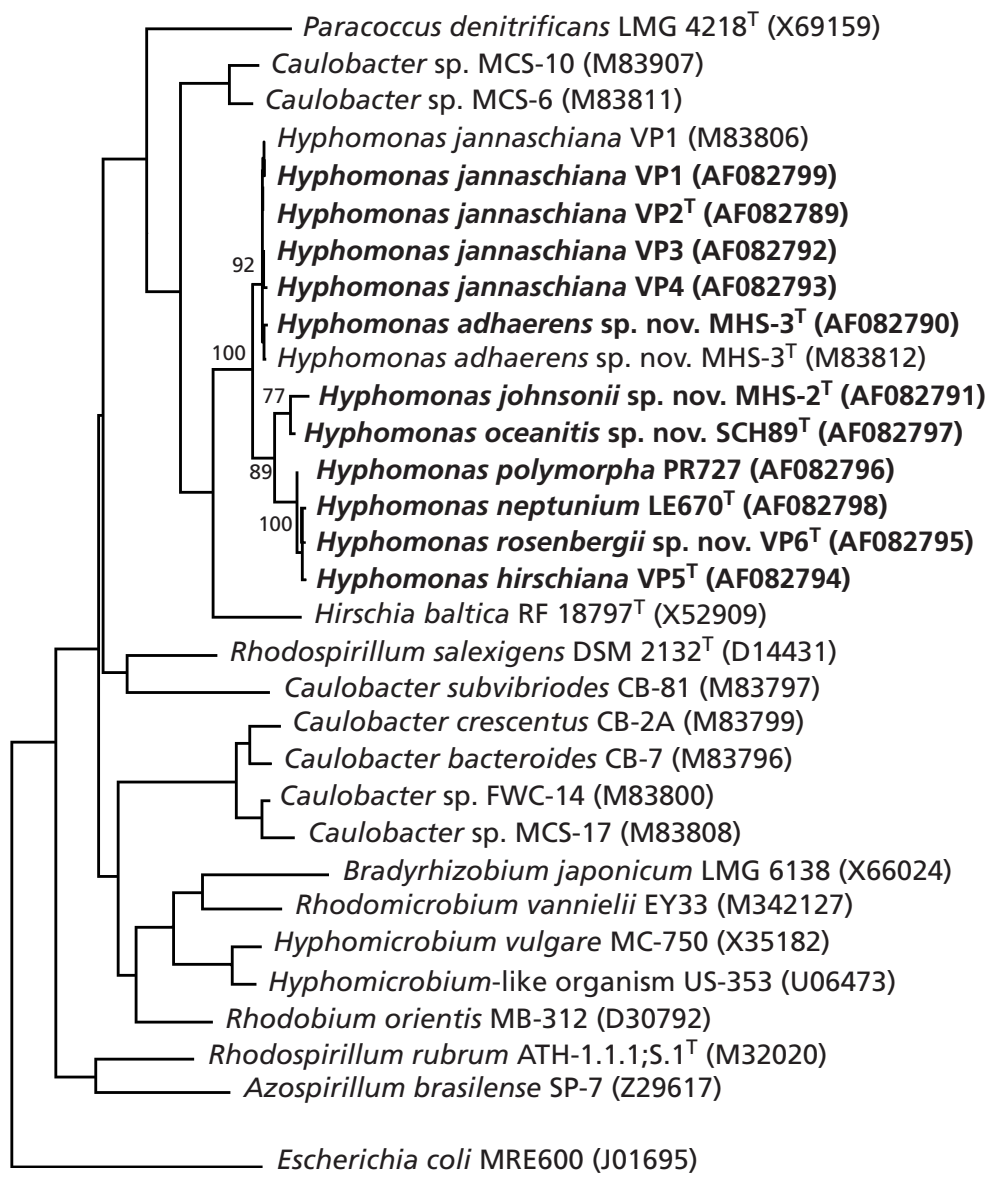

$0 \cdot 10$

\begin{abstract}
Fig. 3. Phylogenetic analysis of Hyphomonas. The tree was constructed using the fast DNA maximum-likelihood program from the RNA Database Project (Larsen et al., 1993). Sequences obtained in this study are in bold type. Sequences used for comparison were obtained from the RNA Database Project (Larsen et al., 1993). Bootstrap values (expressed as percentages of 100 replications), pertinent to Hyphomonas species, are shown at the appropriate branch points. Escherichia coli MRE600 was used as an outgroup to establish the root of the tree.
\end{abstract}

to Hyphomonas hirschiana and support both of the two species groupings, i.e. Hyphomonas adhaerens sp. nov. and Hyphomonas jannaschiana plus Hyphomonas johnsonii sp. nov. and Hyphomonas oceanitis. On the other hand, the DNA-DNA hybridization data suggest that Hyphomonas neptunium forms a tighter relationship with Hyphomonas adhaerens sp. nov. on the basis of DNA-DNA homology values than on the basis of 16S rDNA sequence comparisons. However, DNA-DNA homology values can be inflated by shared plasmids and other forms of horizontal genetic exchange.

The possibility was considered, and the serological identities hinted, that the vent prosthecate strains (VP1-VP6 ${ }^{\mathrm{T}}$ ) could form a sub-group within Hyphomonas since each was isolated from the deep sea, each was barophilic and each came from dynamic niches with respect to temperature and ion concentration. Indeed, the VP strains, especially VP1-VP4, were phenotypically more 'plastic' (i.e. able to flourish in a wide variety of environmental conditions). However, genotypically, Hyphomonas jannaschiana, Hyphomonas hirschiana and Hyphomonas rosenbergii sp. nov. grouped as strongly, or more strongly, with species isolated from non-vent ocean niches as with one another. For example, Hyphomonas adhaerens sp. nov. MHS- $3^{\mathrm{T}}$ and Hyphomonas jannaschiana VP1 had a higher 16S rDNA similarity matrix with one another than with Hyphomonas hirschiana $\mathrm{VP}^{\mathrm{T}}$ or Hyphomonas rosenbergii $\mathrm{sp}$. nov. $\mathrm{VP}^{\mathrm{T}}$. Thus, it appears that Hyphomonas is a group of pelagic 'wanderers', able to colonize (and possibly adapt to) different solid, submerged substrata, including those near hydrothermal vents.

\section{Amended description of genus Hyphomonas}

Hyphomonas species are of marine origin, share a biphasic life cycle and normally generate only a single polar prosthecum. They catabolize amino acids for energy and growth (with the exception of strain MHS-2 ${ }^{\mathrm{T}}$, which can utilize sugars). They are isolated from many ocean niches, including the open ocean (the pelagic zone), mud sloughs and two different hydrothermal vent sites (surface waters and depths of $2600 \mathrm{~m}$ ). Members of the genus Hyphomonas, like other budding, prosthecate bacteria, undergo a rather complex life cycle termed a 'biphasic life cycle'. It requires $265 \mathrm{~min}$ for Hyphomonas neptunium to complete a full cycle at $36{ }^{\circ} \mathrm{C}$. The life cycle consists of 
a swarm-cell stage that eventually metamorphoses into a benthic, reproductive cell during the biphasic developmental cycle. Members of Hyphomonas, especially the vent strains, grow in a broad range of environmental conditions, including those involving considerable temperature, pressure and salinity variations. They are primary colonizers of submerged marine surfaces, some species producing dense biofilms.

Briefly, the morphological characteristics of Hyphomonas cells are as follows: rod-shaped to oval mature cells measuring $0.5-1.0 \times 1.0-3.0 \mu \mathrm{m}$; buds are produced at the tips of polar prosthecae, which measure $0 \cdot 2-0 \cdot 3 \mu \mathrm{m}$ in diameter and are $1-5$ times the length of the cell body; and swarm cells are motile by means of a single polar to lateral flagellum located on developing buds of younger daughter cells.

Gram-negative, non-acid-fast, aerobic, non-sporeforming and chemo-organotrophic. All strains investigated so far are catalase-positive, oxidase-positive, urease-negative, indole-negative, hydrogen sulfidenegative, non-saccharolytic and non-pathogenic for mammals. Peptone is normally required for growth. With one exception, all strains denitrify. The optimum growth temperature range is $22-37^{\circ} \mathrm{C}$ at $101 \mathrm{kPa}$. Hyphomonas neptunium, Hyphomonas polymorpha, Hyphomonas oceanitis and Hyphomonas hirschiana have a Q-11 ubiquinone type along with a significant amount of Q-10 (approx. 10\% of total ubiquinones) and minor amounts of Q-9 and Q-12. Hyphomonas jannaschiana has Q-10 as its major quinone, with trace amounts of Q-9 and Q-11. Synthesize many apparent high-molecular-mass proteins $(\geqslant 64 \mathrm{kDa})$. The dominant fatty acid, common to all Hyphomonas spp., is octadecenoic acid $(18: 1)$. The $\mathrm{G}+\mathrm{C}$ content of the DNA is $57-64 \mathrm{~mol} \%$.

\section{Description of Hyphomonas adhaerens sp. nov.}

Hyphomonas adhaerens (ad.hae'rens. L. part. adj. adhaerens hanging on/sticking to).

The main body of the mother cell is prolate spheroid, approximately $1-2 \mu \mathrm{m}$ in diameter and has one prosthecum $0 \cdot 2 \mu \mathrm{m}$ wide $\times 1-5 \mu \mathrm{m}$ long. Buds are motile by a single flagellum. The main body of the reproductive cell, but not the prosthecum, is surrounded by capsular polysaccharide. Gram-negative. Not acid-fast. No endospores. Aerobic. Colonies are round, undulate and about $1.5 \mathrm{~mm}$ in diameter after $3 \mathrm{~d}$ at $30^{\circ} \mathrm{C}$ on marine agar. In liquid media, there is granular turbidity due to adhering cell masses. A thick biofilm forms on the surface of the growth vessel. Do not form rosettes. The optimum temperature range is $25-37^{\circ} \mathrm{C}$. The ocean salts growth range is $1 \cdot 5-12 \%$. The optimum $\mathrm{pH}$ growth range is 5.7-8.7. Nitrate is reduced. Sheep erythrocytes are not haemolysed. Susceptible to novobiocin, streptomycin, tellurite, crystal violet, brilliant green and methylene blue but resistant to $1.0 \%$ Tween 80 , penicillin and ampicillin.
The major fatty acid is octadecanoic acid (18:1), constituting $80 \%$ of the total fatty acids. The $\mathrm{G}+\mathrm{C}$ content of the DNA is $60 \mathrm{~mol} \%$. The type strain is MHS $-3^{\mathrm{T}}\left(=\right.$ ATCC $\left.43965^{\mathrm{T}}\right)$.

\section{Description of Hyphomonas johnsonii sp. nov.}

Hyphomonas johnsonii (john.so'nii. M.L. gen. n. johnsonii of Johnson, named after the American molecular taxonomist John Johnson).

The main body of the mother cell is prolate spheroid, approximately $1 \mu \mathrm{m}$ in diameter and has one prosthecum $0.2 \mu \mathrm{m}$ wide $\times 1 \mu \mathrm{m}$ long. Buds are motile by a single flagellum. Gram-negative. Not acid-fast. No endospores. Aerobic. Colonies are round, convex and approximately $1.5 \mu \mathrm{m}$ in diameter after $3 \mathrm{~d}$ at $30{ }^{\circ} \mathrm{C}$ on marine agar. In liquid medium, growth is granular and/or ropey. A thin film may form on the growth vessel. Can utilize sugars, in the presence of amino acids for carbon and energy. The optimum temperature range is $25-37^{\circ} \mathrm{C}$. The ocean salts growth range is $1 \cdot 5-6 \cdot 0 \%$. The $\mathrm{pH}$ growth range is $5 \cdot 7-8 \cdot 0$. Nitrate is reduced. Sheep erythrocytes are $\alpha$ haemolysed. Susceptible to novobiocin, penicillin, ampicillin, streptomycin, tellurite, crystal violet and brilliant green but resistant to $1.0 \%$ Tween 80 , methylene blue and neutral red. The major fatty acid is octadecanoic acid (18:1), constituting $64 \%$ of the total fatty acids. The outer-membrane-protein profiles, DNA homology and serology have low but significant identity with other strains of Hyphomonas. The $\mathrm{G}+\mathrm{C}$ content of the DNA is $64 \mathrm{~mol} \%$. The type strain is MHS $-2^{\mathrm{T}}\left(=\right.$ ATCC $\left.43964^{\mathrm{T}}\right)$.

\section{Description of Hyphomonas rosenbergii sp. nov.}

Hyphomonas rosenbergii (ro.sen.ber'gi.i. M.L. gen. n. rosenbergii of Rosenberg, named after the Israeli microbial ecologist Eugene Rosenberg).

The main body of the mother cell is prolate spheroid, approximately $1 \mu \mathrm{m}$ in diameter and has one prosthecum $0 \cdot 2 \mu \mathrm{m}$ wide $\times 1 \mu \mathrm{m}$ long. Buds are motile by a single flagellum. Synthesizes a capsule that surrounds the entire cell at all growth stages and a polar holdfast that is temporally synthesized. Gramnegative. Not acid-fast. No endospores. Aerobic. Colonies are round, convex and approximately $1.5 \mu \mathrm{m}$ in diameter after $3 \mathrm{~d}$ at $37^{\circ} \mathrm{C}$ on marine agar. In liquid medium, growth is granular and/or ropy. A biofilm forms on the walls of the growth vessel. Cells form rosettes. The optimum temperature range is $25-45^{\circ} \mathrm{C}$. The ocean salts growth range is $1 \cdot 0-2 \cdot 0 \%$. The $\mathrm{pH}$ growth range is 5.7-8.9. Nitrate is reduced. Sheep erythrocytes are not haemolysed. Susceptible to novobiocin, penicillin, ampicillin, streptomycin, tellurite, crystal violet, brilliant green and methylene blue but resistant to $1.0 \%$ Tween 80 and neutral red. The major fatty acid is octadecanoic acid (18:1), constituting $43 \%$ of the total fatty acids. The outer-membraneprotein profiles, DNA homology and serology have 
low but significant identity with other strains of Hyphomonas. The $\mathrm{G}+\mathrm{C}$ content of the DNA is $61 \mathrm{~mol} \%$. The type strain is VP6 $6^{\mathrm{T}}\left(=\right.$ ATCC $\left.43869^{\mathrm{T}}\right)$.

\section{ACKNOWLEDGEMENTS}

We thank F. Singleton for the fatty acid analysis, R. Gherna for the $\mathrm{G}+\mathrm{C}$ determinations, and $\mathrm{H}$. G. Trüper for providing the etymologies. G. Lacy and J. Johnson generously contributed their time, expertise and laboratories for the DNA-DNA hybridizations. K. Guthrie and K. Busch provided valuable technical assistance. We thank S. M. Hinton and the Exxon Research \& Engineering Corporation for their contributions to the $16 \mathrm{~S}$ rDNA analysis. H. Jannasch and J. Smit graciously provided Hyphomonas strains. This manuscript was prepared courtesy of a University MD Graduate School Semester Research Award (to R.W.) and a portion of this work was supported by a grant from JIFSAN.

\section{REFERENCES}

Baier, R., Meyer, A., DePalma, V., Krieg, R. \& Fornalik, M. (1983). Surface microfouling during the induction period. J Heat Trans 105, 618-624.

Batrakov, S. G., Nikitin, D. I. \& Pitryuk, I. A. (1996). A novel glycolipid, 1,2-diacyl-3-alpha-D-glucuronopyranosylsn-glycerol taurineamide, from the budding seawater bacterium Hyphomonas jannaschiana. Biochim Biophys Acta 1302, 167-176.

Baty, A. M., Frolund, B., Geesey, G. G., Langille, S., Quintero, E. J., Suci, P. A. \& Weiner, R. M. (1996). Adhesion of biofilms to inert surfaces: a molecular level approach directed at the marine environment. Biofouling 10, 111-121.

Bowden, G. H. W. (1993). Serological identification. In Handbook of New Bacterial Systematics, pp. 429-455. Edited by M. Goodfellow \& A. G. O’Donnell. New York: Academic Press.

Bowman, J. P., McCammon, S. A., Brown, M. V., Nochols, D. S. \& McMeekin, T. A. (1997). Diversity and association of psychrophilic bacteria in Antarctic Sea ice. Appl Environ Microbiol 63, 3068-3078.

Chang, Y., Coon, S., Walch, M. \& Weiner, R. M. (1996). Effects of Hyphomonas biofilms on the toxicity of copper and zinc to Crassostrea gigas and C. virginica larval set. J Shellfish Res 15, 589-595.

Dagasan, L. \& Weiner, R. M. (1986). Contribution of the electrophoretic pattern of cell envelope protein to the taxonomy of Hyphomonas spp. Int J Syst Bacteriol 36, 192-196.

DeWeger, L. A., Jann, B. \& Lugtenbung, B. (1987). LPS of Pseudomonas species that stimulate plant growth: comparison and use for strain identification. J Bacteriol 169, 1441-1446.

Duchow, E. \& Douglas, H. C. (1949). Rhodomicrobium vannielli, a new photoheterotrophic bacteria. J Bacteriol 58, 409-416.

Felsenstein, J. (1993). PHYLIP (Phylogeny Inference Package), version 3.5, Department of Genetics, University of Washington, Seattle, WA, USA.

Frolund, B., Suci, P. A., Langille, S., Weiner, R. M. \& Geesey, G. G. (1996). Influence of protein conditioning films on binding of a bacterial polysaccharide adhesin from Hyphomonas MHS-3. Biofouling 10, 17-30.

Gebers, R., Moore, R. L. \& Hirsch, P. (1984). Physiological properties and DNA-DNA homologies of Hyphomonas polymorpha and Hyphomonas neptunium. Syst Appl Microbiol 5, $510-517$.
Gebers, R., Wehmeyer, U., Roggentin, U. T., Schlesner, H., KolbelBoelke, J. \& Hirsch, P. (1985). Deoxyribonucleic acid base composition and nucleotide distributions of 65 strains of budding bacteria. Int J Syst Bacteriol 35, 260-269.

Gebers, R., Martens, B., Wehmeyer, U. \& Hirsch, P. (1986). Deoxyribonucleic acid homologies of Hyphomicrobium spp., Hyphomonas spp., and other hyphal, budding bacteria. Int $J$ Syst Bacteriol 36, 241-245.

Harder, W. R., Matin, A. \& Attwood, M. M. (1975). Studies on the physiological significance of the lack of a pyruvate dehydrogenase complex in Hyphomicrobium sp. J Gen Microbiol 86, 319-326.

Havenner, J. A., McCardell, B. A. \& Weiner, R. M. (1979). Development of defined, minimal, and complete media for the growth of Hyphomicrobium neptunium. Appl Environ Microbiol 38, 18-23.

Hirsch, P. (1974). Budding bacteria. Annu Rev Microbiol 28, 391-444.

Jannasch, H. W. \& Wirsen, C. O. (1981). Morphological survey of microbial mats near deep sea hydrothermal vents. Appl Environ Microbiol 41, 528-538.

Johnson, J. L. (1984). Nucleic acids in bacterial classification. In Bergey's Manual of Systematic Bacteriology, vol. 1, pp. 8-11. Edited by N. R. Krieg \& J. G. Holt. Baltimore: Williams \& Wilkins.

Johnson, J. L. (1994). Similarity analysis of DNAs. In Methods of General and Molecular Microbiology, pp. 655-682. Edited by P. Gerhardt, R. G. E. Murray, W. A. Wood \& N. R. Krieg. Washington, DC: American Society for Microbiology.

Kolbel-Boelke, J., Gebers, R. \& Hirsch, P. (1985). Genome size determinations for 33 strains of budding bacteria. Int J Syst Bacteriol 35, 270-273.

Kotob, S., Coon, S., Quintero, E. \& Weiner, R. (1995). Homogentisic acid is the primary precursor of melanin synthesis in Vibrio cholerae, Hyphomonas sp. and Shewanella colwelliana. Appl Environ Microbiol 61, 1620-1622.

Langille, S. \& Weiner, R. M. (1998). Spatial and temporal production of Hyphomonas VP6 extracellular polymeric substances. Appl Environ Microbiol 64, 2906-2913.

Larsen, N., Olsen, G. J., Maidak, B. L., McCaughey, M. J., Overbeek, R., Macke, T. J., Marsh, T. L. \& Woese, C. R. (1993). RNA Database Project. Nucleic Acids Res 21, 191-198.

Lechevalier, H. \& Lechevalier, M. P. (1988). Chemotaxonomic use of lipid - an overview. In Microbial Lipids, pp. 869-902. Edited by D. Ratledge \& F. G. Wilkinson. New York: Academic Press. Liefson, E. (1964). Hyphomicrobium neptunium sp. nov. Antonie Leeuwenhoek 30, 249-256.

Mandel, M., Hirsch, P. \& Conti, S. F. (1972). DNA base compositions of Hyphomicrobia. Arch Mikrobiol 81, 289-294.

Marmur, J. (1961). A procedure for the isolation of DNA from microorganisms. J Mol Biol 3, 208-218.

Moore, R. L. (1977). Ribosomal ribonucleic acid cistron homologies among Hyphomicrobium and various other bacteria. Can J Microbiol 23, 478-481.

Moore, R. L. (1981). The biology of Hyphomicrobium and other prosthecate, budding bacteria. Annu Rev Microbiol 35, 567-594.

Moore, R. L. \& Hirsch, P. (1972). Deoxyribonucleic acid base sequence homologies of some budding and prosthecate bacteria. $J$ Bacteriol 110, 256-261.

Moore, R. L. \& Hirsch, P. (1973). Nuclear apparatus of Hyphomicrobium. J Bacteriol 116, 1447-1455. 
Moore, R. L. \& Weiner, R. M. (1984). Budding and/or appendaged bacteria. In Bergey's Manual of Systematic Bacteriology, vol. 3, pp. 1904-1910. Edited by J. T. Staley, M. P. Bryant, N. Pfennig \& J. G. Holt. Baltimore: Williams \& Wilkins.

Moore, R. L., Weiner, R. M. \& Gebers, R. (1984). Genus Hyphomonas Pongratz 1957 nom. rev. emend., Hyphomonas polymorpha Pongratz 1957 nom. rev. emend., and Hyphomonas neptunium (Leifson 1964) comb. nov. emend. (Hyphomicrobium neptunium). Int J Syst Bacteriol 34, 71-73.

Nikitin, D. I. \& Nikitina, E. S. (1978). Environmental processes of self-clarifying and bacterial parasites (genus Bdellovibrio). Nauka Moscow, p. 26.

Nikitin, D. I., Vishnewetskaya, G. Y., Chumakov, K. M. \& Zlatkin, I. V. (1990). Evolutionary relationship of some stalked and budding bacteria (genera Caulobacter, "Hyphobacter", Hyphomonas, and Hyphomicrobium) as studied by the new integral taxonomic method. Arch Microbiol 153, 123-128.

Poindexter, J. S. (1981). The Caulobacters: ubiquitous unusual bacteria. Microbiol Rev 76, 123-179.

Pongratz, E. (1957). D'une bactérie pediculé isolé d'un pus de sinus. Shweiz Z Allg Pathol Bakteriol 20, 593-608.

Quintero, E. J. \& Weiner, R. M. (1995). Evidence for the adhesive function of the exopolysaccaride of Hyphomonas strain MHS-3 in its attachment to surfaces. Appl Environ Microbiol 61, 1897-1903.

Quintero, E. J., Busch, K. \& Weiner, R. M. (1998). Spatial and temporal deposition of adhesive extracellular polysaccharide capsule and fimbriae by Hyphomonas MHS-3. Appl Environ Microbiol 64, 1246-1255.

Roggentin, T. \& Hirsch, P. (1989). Ribosomal RNA cistron similarities among Hyphomicrobium sp. and several other hyphal, budding bacteria. Syst Appl Bacteriol 11, 140-147.

Schlesner, H., Bartels, C., Sittig, M., Dorsch, M. \& Stackebrandt, E. (1990). Taxonomic and phylogenetic studies on a new taxon of budding hyphal Proteobacteria, Hirschia baltica gen. nov., sp. nov. Int $J$ Syst Bacteriol 40, 443-451.

Shen, N., Dagasan, L., Sledjeski, D. \& Weiner, R. M. (1989). Major outer membrane proteins unique to reproductive cells of Hyphomonas jannaschiana. J Bacteriol 171, 2226-2228.

Sittig, M. \& Hirsch, P. (1992). Chemotaxonomic investigation of budding and/or hyphal bacteria. Syst Appl Bacteriol 15, 209-222.

Sittig, M. \& Schlesner, H. (1993). Chemotaxonomic investigation of various prosthecate and/or budding bacteria. Syst Appl Bacteriol 16, 92-103.

Sledjeski, D. \& Weiner, R. (1991). Homogeneity of R-type lipopolysaccharides of marine bacteria. Appl Environ Microbiol 57, 2094-2096.
Smibert, R. \& Krieg, N. (1981). General characterization. In Manual of Methods for General Bacteriology, pp. 409-443. Edited by P. Gerhardt. Washington, DC: American Society for Microbiology.

Stackebrandt, E., Fischer, A., Roggentin, T., Wehmeyer, U., Bomar, D. \& Smida, J. (1988). A phylogenetic survey of budding and/or prosthecate, non-phototrophic eubacteria: membership of Hyphomicrobium, Hyphomonas, Pedomicrobium, Filomicrobium, Caulobacter and "Dichotomicrobium" to the alpha-subdivision of purple non-sulfur bacteria. Arch Microbiol 149, 547-556.

Stahl, D. A., Key, R., Flesher, B. \& Smit, J. (1992). The phylogeny of marine and freshwater Caulobacters reflects their habitat. J Bacteriol 174, 2193-2198.

Staley, J. T., Marshall, K. C. \& Skerman, V. B. D. (1980). Budding and prosthecate bacteria from freshwater habitats of various trophic states. Microb Ecol 5, 245-251.

Stutzer, A. \& Hartleb, R. (1898). Untersuchungen über die bei der Bildung von Salpeter beobachtetn Mikroorganismen. Abh Mitt Landwirtsch Inst Koniglichen Univ Breslau 1, 75-100.

Urakami, T. \& Komagata, K. (1987). Characterization and identification of methanol-utilizing Hyphomicrobium strains and a comparison with species of Hyphomonas and Rhodomicrobium. J Gen Appl Microbiol 33, 521-542.

Vauterin, L., Swings, J. \& Kersters, K. (1993). Protein electrophoresis and classification. In Handbook of New Bacterial Systematics, pp. 251-280. Edited by M. Goodfellow \& A. G. O'Donnell. New York: Academic Press.

Wali, T., Hudson, G. R., Danald, D. A. \& Weiner, R. M. (1980). Timing of swarmer cell cycle morphogenesis and macromolecular synthesis by Hyphomicrobium neptunium in synchronous culture. J Bacteriol 144, 406-412.

Weidner, S., Arnold, W. \& Puhler, A. (1996). Diversity of uncultured microorganisms associated with the seagrass Halophila stipulacea estimated by restriction fragment length polymorphism analysis of PCR-amplified 16S rRNA genes. Appl Environ Microbiol 62, 766-771.

Weiner, R. M., Devine, R., Powell, D., Dagasan, L. \& Moore, R. (1985). Hyphomonas oceanitis sp. nov., Hyphomonas hirschiana sp. nov., and Hyphomonas jannaschiana sp. nov. Int J Syst Bacteriol 35, 237-243.

Werman, S. D., Springer, M. S. \& Britten, R. J. (1996). Nucleic acids I: DNA-DNA hybridization. In Molecular Systematics, pp. 169-203. Edited by D. M. Hillis, C. Moritz \& B. K. Mable. Sunderland, MA: Sinauer.

Zerfas, P., Kessel, M., Quintero, E. \& Weiner, R. M. (1997). Fine structure evidence for cell membrane partitioning of the nucleoid and cytoplasm during bud formation in Hyphomonas. J Bacteriol 179, 148-156. 